\title{
KULTURA \\ i

\section{AKTYWNOŚĆ FIZYCZNA, (NIEPEŁNO)SPRAWNOŚĆ I ZDROWIE W REKLAMACH NAJWIĘKSZYCH IMPREZ SPORTOWYCH ŚWIATA}

\section{SPORT PRZEDMIOTEM REFLEKSJI NAUKOWEJ}

Do końca XX wieku filozofia sportu, socjologia kultury fizycznej i socjologia niepełnosprawności uchodziły w Polsce za akademickie „brzydkie kaczątka”. Sytuacja zmienia się jednak. „Sport, traktowany bardzo długo jako «akademicki kopciuszek", przyciąga coraz bardziej uwagę akademików - filozofów, socjologów, psychologów, kulturoznawców, etnologów - stając się przedmiotem wielu teoretycznych opracowań i debat. W tych dyskusjach rozpatrywany jest on nie tylko jako jeden $z$ fenomenów współczesnej kultury masowej, ale także jako żywotny i uniwersalny etos o prastarym przecież rodowodzie, niemarginalny komponent kultury, jedna ze spektakularnych enklaw społecznych zachowań człowieka" (Zowisło 2007, s. 27). Tematyką związaną z kondycją fizyczną, sprawnością ruchową, sportem, wychowaniem fizycznym i zdrowiem oraz chorobami i niepełnosprawnościami zajmowali się nieliczni badacze, głównie z Akademii Wychowania Fizycznego i Uniwersytetów Medycznych. Podczas VI Międzynarodowego Sympozjum Socjologii Sportu Antonina Kłoskowska stwierdziła: „Jak wykazują badania i potoczna obserwacja, tylko bardzo niewielu mężczyzn nie interesuje się sportem, a wzrastająca liczba kobiet zaczyna się sportem interesować. A więc ogromna część — znacznie więcej aniżeli połowa członków społeczeństw współczesnych — sportem interesuje się. To wystarczy, aby uczynić owo zjawisko przedmiotem zainteresowań teoretycznych i rozważać także jego praktyczną rangę" (cyt. za: Krawczyk 2011, s. 26). 
Dziś wiemy, jak ważnym elementem rzeczywistości społecznej jest sport, a w aktywności fizycznej dostrzegamy remedium na bolączki współczesnego świata i problemy zdrowotne ludzi w nim żyjących. Hans Georg Gadamer (2011, s. 7) konstatuje: „Nigdzie indziej postęp nowoczesnego badania naukowego nie wkracza tak silnie w pole napięć społeczno-politycznych", jak w obszarze dotyczącym chorób cywilizacyjnych, niepełnosprawności i starości, które stały się globalnymi problemami społecznymi. Chorych, niepełnosprawnych i seniorów przybywa, Europa gwałtownie się starzeje. Antonina Ostrowska stwierdza: „Sytuacja życiowa i miejsce zajmowane w społeczeństwie przez ludzi niepełnosprawnych jest wypadkową wielu czynników. Poza parametrami zdrowotnymi, funkcjonalnymi, psychicznymi, decyduje o niej szereg uwarunkowań micro-i makrospołecznych. Są to zarówno cechy położenia społecznego, posiadane kwalifikacje czy sytuacja rodzinna osoby niepełnosprawnej, jak i sytuacja ekonomiczna kraju, obowiązujące regulacje prawne, kierunek polityki społecznej" (Ostrowska 2015, s. 8).

Laureat Pokojowej Nagrody Nobla, wieloletni prezydent RPA, Nelson Mandela, otwierając $\mathrm{w} 2010$ roku na wózku inwalidzkim pierwsze afrykańskie mistrzostwa świata w piłce nożnej, był zdania, że sport jest uniwersalnym językiem komunikacji, umożliwiającej dialog $z$ dyskryminowanymi grupami społecznymi (cyt. za: Jagielski 2013, s. 45). Inny laureat Pokojowej Nagrody Nobla z RPA, pierwszy czarnoskóry arcybiskup Kapsztadu, Desmond Tutu i Jan Paweł II — znany z zamiłowania do sportu filozof - wielokrotnie przemawiali do rzesz wiernych na największych stadionach świata. Papież przestrzegał: „Aby był to sport, który chroni słabych i nie wyklucza nikogo, uwalnia młodych z sideł apatii i obojętności i wzbudza w nich wolę zdrowego współzawodnictwa" (Jan Paweł II 2005, s. 10-11).

Od 1960 roku igrzyska olimpijskie są transmitowane przez telewizję, co znacząco wpłynęło na ich oglądalność i rozpoczęło nową erę w przekazach sportowych. Dziś niewyobrażalne jest, aby kluczowe media, publiczne i prywatne, nie pokazywały tak ważkiego społecznie wydarzenia, jakim jest Euro czy Mundial, ceremonia otwarcia i zamknięcia igrzysk olimpijskich. Sport stał się, trawestując słowa Karola Marksa, „opium dla ludu” (zob. Antonowicz, Wrzesiński 2009, s. 115-149; Sahaj 2009, s. 137-161). Pierre Bourdieu twierdzi, że telemetria jest dziś fetyszyzowana, a obrazy w kalejdoskopowych odbiciach zmieniają się w symulakry. Jürgen Habermas z kolei uważa, że media zawłaszczają i uzależniają od siebie masowego widza, albowiem „[...] skończyła się definitywnie epoka sportu dla sportowców, a zaczęła era sportu dla publiki, ze wszystkimi tego stanu konsekwencjami" (zob. Lipiec 2007, s. 336). Widowiska sportowe nabrały charakteru autotelicznego, a kibic stał się specyficznym aktorem społecznym - homo zappiens - dokonującym telewizyjnym pilotem społecznie znaczących wyborów. W przestrzeni publicznej nastąpiło coś, co można nazwać „sportyzacją": sport się ogląda i o sporcie się mówi oraz, coraz częściej, sport się uprawia; panuje moda na aktywność ruchową. Obecność sportu w mediach 
i w naszym życiu stała się ważnym fragmentem codzienności. Piotr Sztompka ujmuje to tak: „Obiad w pracy i msza niedzielna, zakupy w markecie i złożenie wieńca pod pomnikiem, mecz piłkarski i koncert symfoniczny [...] [stanowią] równorzędne elementy życia codziennego" (Sztompka 2008, s. 24).

Wydarzenia sportowe towarzyszą nam na co dzień i od święta. Na początku 2014 roku ponad 111 mln Amerykanów obejrzało finał Super Bowl futbolu amerykańskiego (ligi zawodowej, National Football League, NFL). Wielu z nich sformułowało oczekiwanie, by był to dzień wolny od pracy, oficjalne święto państwowe wpisane do amerykańskiej konstytucji. Pod petycją do pierwszego czarnoskórego prezydenta Stanach Zjednoczonych Baracka Obamy podpisało się ponad sto tysięcy osób. Pod względem poziomu konsumpcji Super Bowl plasuje się tuż obok Święta Dziękczynienia i Dnia Niepodległości. Wielogodzinne transmisje telewizyjne przeplatane są mnogością reklam. Robert D. Putnam dostrzega interesującą tendencję: „O ile uprawianie sportu zajmuje Amerykanom coraz mniej czasu, o tyle jego oglądanie zjada więcej ich czasu i pieniędzy niż kilkadziesiąt lat temu. Liczba widzów zwiększyła się bardzo gwałtownie [...]. Częściowo wzrost oglądalności imprez sportowych odzwierciedla zmianę naszych nawyków związanych z oglądaniem telewizji, jednak znajduje on również swój wyraz we wzroście liczby osób oglądających wydarzenia na żywo. [...] uczestnictwo w ważniejszych imprezach sportowych uległo od lat 60. niemal podwojeniu" (Putnam 2008, s. 193).

Marshall McLuhan w masowych mediach widzi przyczynę sprawczą zmian społecznych w Stanach Zjednoczonych, a jako jeden z wielu przykładów podaje przesunięcie zainteresowania $z$ baseballu na futbol amerykański, bardziej, jego zdaniem, oddający „amerykańskiego ducha”. Pisał on o zmianach postaw wynikających z oddziaływania diametralnie odmiennej techniki. „To właśnie angażująca odbiorcę sieć obrazu telewizyjnego przepowiada w szczególności przynajmniej chwilowy zmierzch baseballu. Baseball jest bowiem gra polegającą na kolejnym wykonywaniu poszczególnych czynności, grą stałych pozycji i w widoczny sposób wyznaczanych specjalistycznych ról, które należą do mijającej epoki mechanizacji, z jej rozdrobnionymi zadaniami i sztabowo-liniową organizacją zarządzania. Telewizja, jako symbol nowych, zbiorowych i angażujących sposobów elektrycznego życia, promuje nawyki jednolitej świadomości i społecznej zależności, które oddalają nas od szczególnego stylu właściwego dla baseballu, z jego naciskiem na specjalizację i pozycyjność. Gdy zmieniają się kultury, zmieniają się również gry” (McLuhan 2004, s. 312).

Baseball, ustępując pola dynamiczniejszemu, nowocześniejszemu i „bardziej społecznemu" futbolowi amerykańskiemu, skazany został na umizgi do chimerycznej i kapryśnej telewizji, podobnie jak będący „fenomenem wyspowym", niszowy żużel w Polsce (McLuhan 2004, s. 417; zob. też Lipoński 2012, s. 521-528; Mazurkiewicz 2014).

W Europie ekscytację wywołują ceremonie otwarcia i zamknięcia igrzysk olimpijskich i igrzysk paraolimpijskich; zarówno co do niebotycznych kwot na 
ich przygotowanie, jak i kolejnych rekordów frekwencji i oglądalności. XXII Zimowe Igrzyska Olimpijskie w Soczi w 2014 roku pochłonęły tyle środków, ile wszystkie wcześniejsze zimowe igrzyska razem wzięte: ponad 50 mld dolarów. Ceremonię otwarcia rosyjskich igrzysk oglądało 3 mld ludzi na całym świecie, a jeszcze więcej widowiskową i brawurowo przeprowadzoną ceremonię zamknięcia. Podczas tej drugiej ceremonii Thomas Bach, przewodniczący MKOl (Międzynarodowy Komitet Olimpijski, ang. International Olympic Committee, IOC) orzekł, że igrzyska pozwoliły „[...] zobaczyć twarz nowej Rosji, skutecznej, przyjaznej, patriotycznej i otwartej na świat". Przemawiający po nim notabl określił je jako „fajne”, a wolontariuszy jako „podstawę rosyjskiego społeczeństwa obywatelskiego". Medale igrzysk paraolimpijskich, których przeprowadzenie stanęło pod znakiem zapytania po interwencji nieoznakowanych wojsk rosyjskich na Krymie i ogólnoświatowym zamieszaniu tym wywołanym, po raz pierwszy w historii igrzysk były wytłoczone w języku Braille’a. Internetowy portal www.media2.pl podał, że rozstrzygający o złotym medalu na igrzyskach w Soczi skok Kamila Stocha oglądało na antenie TVP1 blisko 11,5 mln widzów. Przekaz z narciarskiej skoczni był najchętniej oglądanym programem telewizyjnym 2014 roku. Transmisje sportowe w Europie należą do najpopularniejszych programów telewizyjnych, podczas najważniejszych meczów pod względem oglądalności plasując się w pierwszej dziesiątce (Kiedrowski 2016, s. 25).

„Transmisje z Igrzysk Olimpijskich w Pekinie w 2008 roku oglądało łącznie 4,7 mld widzów, a więc ok. 70\% ludzkości" (Rymarczyk 2011, s. 87-88). W czasie ceremonii zamknięcia chińskich igrzysk David Beckham zapowiadał igrzyska olimpijskie w Londynie. Liczba oglądających zmagania sportowe na brytyjskich arenach podczas Igrzysk Olimpijskich w 2012 roku przekroczyła granicę $5 \mathrm{mld}$. Londyńskie igrzyska przeprowadzone $z$ dużym społecznym zaangażowaniem, pod względem oglądalności sprawiły wiele niespodzianek. Jedną z nich było nadzwyczajne zainteresowanie mediów i widzów igrzyskami paraolimpijskimi. Za fenomen społeczny i rekord frekwencji można uznać fakt, że rywalizację sportową w poszczególnych dyscyplinach i konkurencjach sportowych rozgrywanych $\mathrm{w}$ trakcie igrzysk osób niepełnosprawnych śledziło 80-100 tys. widzów szczelnie wypełniających stadiony. Ceremonię otwarcia igrzysk paraolimpijskich pokazywaną w kanale telewizyjnym „Channel 4” oglądało ponad 11 mln Brytyjczyków, a na zawody sprzedano ponad 2 mln biletów. Robert D. Putnam we wspólnotach kibiców i widzów sportowych dostrzega znaczny kapitał: „Spajający kapitał społeczny tworzy pewnego rodzaju socjologiczny superklej, natomiast łączący kapitał społeczny zawiera socjologiczne smarowidło" (Putnam 2008, s. 41).

Wobec tak licznej widowni na obiektach sportowych i przed telewizorami nie dziwi to, że wielkie imprezy sportowe wabią sponsorów, zwłaszcza globalne koncerny, takie jak Coca-Cola (jeden z najstarszych partnerów organizatorów igrzysk olimpijskich), Pepsi-Cola, McDonalds, VISA, Omega, Samsung itp. Ce- 
na emisji trzydziestosekundowego spotu reklamowego $\mathrm{w}$ prime time $\mathrm{w}$ trakcie finałów Super Bowl przekroczyła kwotę 4,5 mln dol. Związek światowego biznesu ze sportem wielkiego formatu jest faktem oczywistym i niezaprzeczalnym, opisanym na gruncie socjologicznym (Burnet 2015, s. 385-390; Horne 2015, s. 466-471; Jacksson 2015, s. 490-495). Podczas globalnych imprez sportowych prezentowane są akcje, kampanie i spoty reklamowe o znacznym stopniu zaangażowania społecznego. Zwraca się w nich uwagę na kwestię chorób cywilizacyjnych (np. otyłości, starości), problemy osób z niepełnosprawnościami, pozytywne i negatywne sposoby spędzania wolnego czasu. Zachęca się do aktywności fizycznej skorelowanej ze zdrowiem, uświadamia kwestie społecznie wrażliwe. W większości analizowanych reklam zastanawia forma przekazu: unika się dydaktyki i moralizatorstwa, a zamiast tego edukuje, stawia na poczucie humoru i zaskakujące asocjacje. Normą jest wykorzystywanie celebrytów, będących lokomotywami tych kampanii. Transmisje ze światowych imprez sportowych są niejako wielkimi telebimami przemawiającymi do milionów odbiorów. Na organiczny związek telewizji ze sportem, zwłaszcza futbolem, stającym się po drugiej wojnie światowej elementem cementującym Europę, zwrócił uwagę Tony Judt (2008, s. 907-911; zob. też Foer 2006), brytyjski historyk przez ostatnie lata życia całkowicie sparaliżowany (Judt 2012).

\section{REKLAMY SPORTOWE JAKO ŹRÓDŁO WIEDZY O SPOŁECZEŃSTWIE}

Mass media, będące uniwersalnym językiem komunikacji globalnego świata, o p ow i a dają c s port w emitowanych obrazach w różnorodny sposób kładą akcenty. Podejmują kwestie dotyczące newralgicznych problemów społecznych, istotnych z socjologicznego punktu widzenia, takich jak choroby cywilizacyjne i niepełnosprawność oraz aktywność fizyczna i zdrowy styl życia, sport traktując jako panaceum na bolączki współczesnego świata, takie jak: otyłość, nadwaga, marginalizowanie grup społecznych, starzenie się społeczeństw. Warto więc poświęcić uwagę treści i formie internetowych i telewizyjnych reklam. Badając je zastosowano metodę jakościową $\mathrm{w}$ postaci analizy zawartości/treści filmów, traktowanych jako specyficzne teksty kultury współczesnej, wchodzące w skład szerszej narracji związanej ze sportem - ważnym składnikiem rzeczywistości społecznej. Z mnogości reklam wybrano te, które wydawały się najbardziej reprezentatywne i transparentne dla omawianego tematu - najczęściej emitowane i oglądane - odnoszą się bowiem do kliku najważniejszych imprez sportowych $z$ lat 2012-2014 ${ }^{1}$.

\footnotetext{
${ }^{1}$ Zamiast tradycyjnych linków jako przypisów do tekstu w nawiasach kwadratowych podawane są słowa kluczowe, pozwalające na identyfikację i odnalezienie filmów na popularnych portalach i w najczęściej używanych internetowych wyszukiwarkach. Ze względu na częste pojawianie się i znikanie filmów w sieci metoda ta zwiększa prawdopodobieństwo dotarcia przez czytelnika do analizowanych obrazów.
} 


\section{Super Bowl - święto komercji i konsumpcji}

Super Bowl 2014 odbył się w nowo wybudowanym obiekcie oddanym do użytku w 2010 roku. Obiekt ten - pisano wówczas (Kiedrowski 2014) „Mieści 83 tysiące kibiców i kosztował 1,6 mld dol. Nie jest zadaszony. Niedzielny Super Bowl będzie pierwszym w historii rozegranym na otwartym stadionie przy mroźnej pogodzie. Przy okazji Super Bowl Amerykanie wydają 12,3 mld dolarów - średnio 68,27 dolarów na konsumenta. Kupują okolicznościowe koszulki, bluzy, czapeczki itp., a także jedzenie, alkohole na zwyczajowe w ten wieczór Super Bowl Party, które organizuje się z przyjaciółmi, by wspólnie oglądać mecz". I wszechobecne reklamy. W bloku reklam emitowanych w 2014 roku na uwagę zasługują te, które były związane z aktywnością fizyczną, sprawnością i zdrowiem. W komercyjnej reklamie H\&M [David Beckham H\&M Super Bowl Commercial 2014] trwale kontuzjowana gwiazda futbolu, która zakończyła karierę sportową, występuje w bieliźnie uprawiając parkkur (city running), skacząc po dachach i zjeżdżając na linie — jak bohater filmów akcji. W reklamie McDonalds potężnie zbudowani amerykańcy futboliści, przygotowując się do meczu, w zabawnym kontekście wypowiadają nazwy dań, dodatków i zestawów związanych z jedzeniem w sieci restauracji [Mcdonalds Super Bowl 2014 Commercial - Lip Reading]. Bruce Willis zachęca do samochodowych ubezpieczeń od następstw nieszczęśliwych wypadków wraz z trzymającym go kurczowo mężczyzną, imitującym pasy bezpieczeństwa [Bruce Willis Honda Super Bowl Commercial 2014]. Scarlett Johansson wywołała zamierzoną kontrowersję, gdy epatując cielesnością i urodą reklamowała domowe urządzenie „Sodastream” do wody sodowej (w założeniu zdrowszej niż gazowane i słodzone napoje), w kulminacyjnym momencie stwierdziła: „sorry cola, sorry pepsi” [Scarlett Johansson Banned Superbowl SodaStream 'Sorry, Coke and Pepsi']. Zwrot ten na zgodne żądanie obu koncernów usunięto na czas emisji reklamy podczas Super Bowl.

Zaskakująca jest reklama z 2013 roku, w której człowiek w podeszłym wie$\mathrm{ku}$, poruszający się na elektrycznym skuterze dla osób niepełnosprawnych, $z$ impetem wdziera się na stadion przygotowany do treningu i szarżuje po śliskiej murawie, traktując infrastrukturę jako tor przeszkód, wchodząc w drift, kręcąc kółka i robiąc stójki. Mimo starań próbującego złapać go ochraniarza „intruz" dokonuje ekwilibrystycznych manewrów. Nie zraża się bolesnymi upadkami: pomagając sobie sprawnymi rękoma wciąga bezwładne kończyny oraz siebie na skuter i kontynuuje rajd. Upojony prędkością i uszczęśliwiony, w geście tryumfu w czasie jazdy podnosi obie ręce i definitywnie wywraca się na plecy. Lakoniczny napis głosi „Buckle up”, co dosłownie znaczy „zapnij pasy” (pasy bezpieczeństwa w samochodzie, samolocie). Jednakże skojarzona $z$ tym data 3 lutego 2013 (dzień rozgrywania finałowego meczu Super Bowl) oraz kontekst (stadion futbolu amerykańskiego) pozwalają odczytać to jako grę słów: „zasiądź w fotelu”, „zakotwicz się” i jedz, bo to reklama barów sieci Taco Bell 
i jej produktów z serii „Live mas” [Taco Bell Viva Mas 2013 Super Bowl Commercial].

Reklama ze swawolnym staruszkiem jest jednym $z$ wielu podobnych przekazów emitowanych przy okazji Super Bowl, tworzących historie, swobodne narracje, wariacje na temat. Jak w reklamie Taco Bell, w której staruszek, mimo że skrępowany w łóżku sznurem i sprawdzony przed snem przez czujną pielęgniarkę, ucieka z domu „spokojnej starości”, choć nie inwalidzkim wózkiem, który stoi przy drzwiach jego pokoju, ale z grupą równolatków czekających na niego w aucie. Podczas ekskursu do miasta pensjonariusze dokazują jak nastolatki: kąpią się w basenie czyjegoś domu, robią psikusy, wizytują kluby nocne pijąc i tańcząc „do białego rana”, oddają się (nie)stosownym namiętnościom, robią sobie tatuaże, jedzą hamburgery leżąc na masce aut, by na koniec strudzeni wrócić o świcie do „domu”.

Koncern Hyundai wyemitował reklamę pokazującą wysiłki społecznie wykluczonych chłopców, którzy dzięki aktywności fizycznej i moralnemu doskonaleniu się są w stanie przeciwstawić się dyskryminującym ich silniejszym rówieśnikom [Official Super Bowl Commercial 2013 Hyundai Santa Fe]. Sloganami reklamowymi były: „Nowe myślenie, nowe możliwości” oraz „Podnieś swój zespół”. Pepsi kilka lat wcześniej wypuściła serię ryzykownych spotów z udziałem kibiców z deficytem słuchu. Na jednym $z$ filmów próbują dojechać do kolegi na imprezę nie pamiętając, gdzie on mieszka (a nie mogąc o to spytać), trąbią więc klaksonem samochodowym dopóty, dopóki włączą się światła we wszystkich domach, poza jednym - właściwym [Super Bowl Pepsi Commercial at Bob's House]. Na początku i na końcu filmu zaznacza się, że jest on stworzony z udziałem i dla osób niepełnosprawnych, a celem twórców było „tworzenie środowiska integrującego osoby o różnych niepełnosprawnościach". W reklamach Pepsi kibice w barwach klubowych żarliwie dyskutują językiem migowym o wyższości preferowanych drużyn futbolowych, w przerwach jedząc hod-dogi i hamburgery popijane pepsi [Pepsi Super Bowl Deaf Comedy Smack Talk]. W spotach reklamujących chipsy Doritos niepełnosprawnymi stają się ludzie nieostrożni, podejmujący zbyt ryzykowne decyzje [Doritos Super Bowl 2014 Commercial].

Reklamy tego typu oraz obecność osób niepełnosprawnych na Super Bowl są elementem poprawności politycznej i szczególnej filozofii działania, jaka jej towarzyszy, ale także pragmatycznego, a zarazem utylitarnego pragnienia multiplikowania zysków koncernów przez zagospodarowanie kolejnych nisz dotychczas wypełnionych marginalizowanymi „zasobami ludzkimi”. W zależności od przyjętych definicji na świecie żyje bowiem 15-20\% osób z niepełnosprawnościami. Oni też są konsumentami: jedzą (chipsy, hamburgery, hod-dogi, pizze), piją (colę, pepsi, piwo, whisky), kupują gadżety klubowe, oglądają i uprawiają sport. Stanowią zatem gigantyczny rynek zbytu i z ekonomicznego oraz społecznego punktu widzenia nie sposób ich zignorować. „Człowiek to największa inwestycja". 


\section{Euro - Mistrzostwa Europy w piłce nożnej}

W odróżnieniu od Amerykanów, w reklamach wzmacniających ekspansywny, konsumpcyjny styl życia, Europejczycy propagując komercję stawiają mocniejsze akcenty na kwestiach społecznych, czynią to w głębszy i bardziej zaangażowany sposób. Europejski Związek Piłki Nożnej (Union of European Football Associations, UEFA), formalny organizator Euro, jest organizacją pragnącą, by jej wizerunek był pozytywnie skorelowany z odpowiedzialnością społeczną. Jednym ze sposobów prezentacji tej polityki działania są emisje spotów reklamowych zachęcających do opuszczenia wygodnych siedzisk i podjęcia aktywności fizycznej. Przykładem jest kampania telewizyjna „Bądź aktywny”, której hasło przewodnie to: „Rusz się. Zejdź ze swojego fotela” [Get Active: TV-campaign to get out of your chair]. W tym karykaturalnym obrazie otyli mężczyźni próbują ociężale rozegrać mecz piłki nożnej na stadionie, nie zsiadając z foteli (w których zwykle oglądają mecze). Komiczny efekt był zamierzony, a nieco większa aktywność niektórych z nich skutkowała co najwyżej tym, że bezwładnie spadali $z$ foteli, $z$ powodu nadwagi niezdolni do wielu ruchów, a przez to niepełnosprawni. Ich motoryka była uboższa niż ludzi poruszających się na inwalidzkich wózkach.

UEFA od lat bezwzględnie i konsekwentnie pilnuje tego, by organizatorzy Euro dbali o potrzeby kibiców niepełnosprawnych, na miarę ich - fanów możliwości ruchowych i potrzeb specjalnych. Dlatego też stadiony w Polsce i na Ukrainie, na których rozgrywano mecze Euro 2012, oraz infrastruktura wokół nich, zostały dostosowane dla osób z różnymi niepełnosprawnościami (niewidomych, na wózkach inwalidzkich i in.). Zabiegom tym towarzyszyła rozbudowana, mająca wielu lokalnych kooperantów, medialna kampania społeczna „Respect”. W założeniu miała ona być przejawem odpowiedzialności społecznej, wykraczającej poza świat sportu, ale w bezpośrednim z nim powiązaniu - jako ważnym medium. Stosowne informacje znajdujemy, wzorem innych koncernów zaangażowanych społecznie („biznes odpowiedzialny społecznie”), na stronach internetowych UEFA (http://www.uefa.org/social-responsibility) i poświęconych Euro (http://www.euro2012respectinclusion.com).

Cztery główne filary kampanii „Respect” to: „szanuj różnorodnośc” (Respect Diversity), „szanuj kulturę kibiców” (Respect Fan Culture), „szanuj niepełnosprawność - piłka bez granic" (Respect Inclusion - Football with No Limits), „szanuj swoje zdrowie” (Respect Your Health). Przy realizacji pierwszego punktu UEFA współpracowała z międzynarodowym stowarzyszeniem Futbol Przeciwko Rasizmowi w Europie (Football Against Racism in Europe, FARE, http://www.farenet.org), zwalczającym szowinizm na stadionach, oraz z polskim stowarzyszeniem „Nigdy Więcej” (http://www.nigdywiecej.org), przeciwstawiającym się ksenofobii, nazizmowi i nietolerancji. Punkt drugi kampanii wspomagało Stowarzyszenie Europejskich Kibiców Piłki Nożnej (Football Supporters Europe, FSE, http://www.fanseurope.org), tworząc ambasady ki- 
bicowskie w ośmiu miastach-gospodarzach Euro 2012. Realizację punktu trzeciego, dotyczącego niepełnosprawnych kibiców, wspierało Centrum Dostępu do Piłki Nożnej w Europie (Centre for Access to Football in Europe, CAFE, http://www.cafefootball.eu), za sprawą którego stadiony były dostosowane do ich możliwości i potrzeb. Punkt czwarty miał wielu organizacyjnych sprzymierzeńców.

Emblemat kampanii „Respect” w reklamach widniał na koszulkach sportowców i sędziów (w tym słynnego arbitra Pierluigi Colliny), stewardów i wolontariuszy. W przekazach telewizyjnych pokazywano przyjacielskie wymiany koszulek dokonywane między ludźmi o różnych kolorach skóry, płci, wieku i pełnionych rolach społecznych [UEFA Respect - TV Ad - Official Euro 2012]. W tej wizerunkowej kampanii piłka nożna, szerzej sport, była prezentowana w kontekście globalnej, ponadnarodowej i ponadpaństwowej platformy porozumienia międzyludzkiego, czytelnego i uniwersalnego języka komunikacji mieszkańców „globalnej wioski”. Twórca tego określenia - Marshall McLuhan — miał rację twierdząc, że „sposób przekazu jest przekazem”. W tym przypadku Euro było świętem raczej niż wojną; festiwalem radości i witalności. Dobrze wyartykułował to Herman Bausinger (2005, s. 272-273): „[...] piłka nożna ma przewagę nad takimi świętami, jak Wielkanoc i Boże Narodzenie. Barwność pisanek wydaje się niemal monotonna w porównaniu z nieskończoną liczbą wariantów meczu piłkarskiego. [...] Święto to jednak nie to samo, co uroczystość - to także rodzaj rytmicznej powtarzalności, o jakiej możemy mówić w przypadku piłki nożnej. Co prawda telewizja i inne media starają się włączyć piłkę nożną do swojej stałej oferty, dostępnej ciągle na żywo lub w powtórkach - dla przeciętnego kibica mecz jest jednak okresowo powracającym wydarzeniem, a nie powszedniością. I jest też, jak każde prawdziwe święto, czymś jedynym w swoim rodzaju. To nie gotowa inscenizacja, którą można zaprezentować publiczności, ale otwarty proces, a mają w nim swój udział wszyscy uczestnicy: gracze na boisku, kibice na trybunach, którzy na swój sposób również grają, a nawet widzowie siedzący przed telewizorem i mający w pamięci swoje własne doświadczenia piłkarskie".

"Otwarty proces”, medialny spektakl, w którym „mają swój udział” wszyscy aktorzy społeczni - działacze, kibice, sędziowie, zawodnicy, został ujęty w reklamach telewizyjnych towarzyszących Euro 2012. Tak ważne wydarzenia sportowo-społeczne owocują niepoliczalną serią reklam eksponowanych co najmniej we wszystkich krajach europejskich. W większości tych reklam znajdujemy nikłe ślady kulturowej obecności gospodarzy zawodów, zwykle w postaci emblematów Euro i UEFA oraz, rzadziej, barw narodowych gospodarzy. Sponsorzy po prostu reklamują swoje komercyjne produkty, wykorzystując do tego celu nadarzające się okazje. Carlsberg, Coca-Cola, McDonalds prezentowały ludyczno-karnawałowe megaparty i zachowania kibiców-konsumentów, które mogły być prezentowane w s zęd zi e, podczas każdych większych zawodów sportowych. W reklamach UEFA była zapowiedź zbliżającej się pił- 
karskiej uczty. Hyundai w szeregu spotów oferował różne modele aut, a jeśli $\mathrm{w}$ jednym $z$ filmów akcja działa się $\mathrm{w}$ Warszawie, to jako tło dla wożenia na dachu samochodu Pucharu UEFA. W reklamie „Determinacja” [Hyundai Euro 2012 Determination TV Commercial] pokazany jest przebieg ewolucji od raczkującego za piłką dziecka do gry pełnowartościowego zawodnika. Firma Nike prezentowała potęgę i żywotność piłki nożnej, ale bez polskich i ukraińskich akcentów. Te pojawiły się w kontrowersyjnej i wywołującej duże emocje internautów reklamie coca-coli [Coca-Cola i hiszpańska reklama obrażająca Polaków]. Jej bohaterem był rezydujący w Hiszpanii emigrant zarobkowy, biedny Polak pracujący na budowie, który ze smutkiem patrzy na plakat informujący o tym, że jego ojczyzna jest organizatorem Euro. W barze wysyła kod z nalepki coca-coli umożliwiający wygranie biletu na mecz, nie ma jednak szczęścia. Współczujący Hiszpanie litościwie oddają mu butelki po wypitej coca-coli, zasilając jego skromny budżet i zwiększając szanse na wygraną. Ambasador Polski w Hiszpanii, Ryszard Schnepf, publicznie zabrał głos w tej sprawie, starając się łagodzić głosy oburzenia wywołane niefortunną reklamą.

W jaki sposób Polacy byli prezentowani w polskich reklamach Euro 2012? Jaki obraz był budowany w masowych mediach? Częściowo na te pytania odpowiada spot reklamowy, przez internautów określany ironicznym mianem „ze zboczeńcem”, choć w internecie należy go szukać pod hasłem „oficjalna promocja UEFA Euro 2012" [Poland Warszawa official promotional UEFA EURO 2012]. Spot wyprodukowany za 5,5 mln zł zrobił nieprzewidzianą przez twórców „karierę”. Nowy Stadion Narodowy, Warszawa i „polskość” reprezentowane były przez parę dynamicznych menadżerów (kobietę i mężczyznę), przed spotkaniem biznesowym uprawiających jogging. Ganiali się oni po bezludnej stolicy Polski, pokonując przestrzeń w magiczny sposób: latając nad miastem, przeskakując nad Wisłą, wdrapując się po ścianach budynków, dokonując akrobatycznych zabiegów i nad wyraz często wykonując karkołomne parkurowe figury $\mathrm{w}$ zimnej scenerii $\mathrm{z}$ betonu, metalu i szkła. Okazjonalnie pojawiają się jacyś ludzie, mający być naszymi reprezentantami: garstka kibiców wymalowanych w barwy narodowe, grupka Żydów, chłopcy grający w piłkę. Spot spotkał się ze zmasowaną krytyką, jako nieudany i zdecydowanie niereprezentatywny. Niewiele w nim Polski, stołeczności, Euro, jest za to wybudowany za 2 mld pusty Stadion Narodowy. Nie ma rozpoznawalnych w świecie Polaków - artystów, celebrytów, polityków, sportowców — poza pomnikiem Chopina.

Aspekty społeczne w znacznie większym stopniu były eksponowane w reklamach komercyjnych. Repozycjonująca się w świadomości społecznej sieć Biedronka postawiła na „Adamiaków” - statystycznych „Kowalskich” wzmacniających grą na boisku reprezentację Polski pod wodzą trenera Franciszka Smudy. Slogan reklamowy głosił: „Biedronka. Wszyscy jesteśmy drużyną narodową". Tesco emitowało autoironiczne sporty odwołujące się do niskiego poziomu gry drużyny narodowej. Miasta, w których odbywały się mecze, postawiły na różne strategie autoprezentacji; Wrocław pokazał się jako „budu- 
jący w rytmie miasta". Globalne koncerny odcinały kupony od organizowanej przez Polaków imprezy, emitując reklamy mające zwiększyć sprzedaż ich produktów. Tak postępowały koncerny samochodowe i sieci handlowe (spożywcze i z branży RTV), nęcąc klientów gadżetami [Real: „Dla klientów wszystko”], wygraną biletów lub wycieczek do krajów będących uczestnikami Euro. Media Markt prowokował, że „nie sponsoruje gwiazdorów futbolu”, ale „sponsoruje kibiców" [Liczą się tylko kibice! Kampania Media Markt]. McDonalds promował „dziecięce eskorty” towarzyszące piłkarzom, a UEFA pokazywała migawki z meczów i radość kibiców, niecierpliwie oczekujących na piłkarskie święto. W komercyjnych reklamach Euro nie uwzględniano osób niepełnosprawnych, choć to oni stali się beneficjentami tej imprezy (Sahaj 2012a, 2012b, 2013a).

\section{Mundial - Mistrzostwa Świata w piłce nożnej}

Ryzykowne wydaje się reklamowanie produktów konsumpcyjnych poprzez wizerunki osób z niepełnosprawnościami. Efekt mógłby być odwrotny od zamierzonego. Zaskakujące jest to, że aktywny sportowo Nick Vujicic, od urodzenia bez czterech kończyn, stał się „twarzą” (w tym kontekście nabiera to szczególnego wymiaru) kampanii reklamowej firmy Hyundai, wspierającej promocję mistrzostw świata w piłce nożnej w RPA w 2010 roku. Globalne imprezy sportowe kojarzą się przecież z najlepszymi i najsilniejszymi sportowcami. Tymczasem w reklamie Mundialu Vujicic pogodnie opowiadał o życiowej tragedii [Nick Vujicic - Copa FIFA Mundial 2010], którą przekuł w sukces finansowy, społeczny i sportowy. W filmowym spocie tłem jego wystąpienia są młodzi ludzie z pasją i radością uprawiający sport. Vujicic zsunąwszy się z inwalidzkiego wózka, fizycznie (i metaforycznie) mozolnie, stopień po stopniu, wskakuje na szczyt wysokich schodów jako żywa egzemplifikacja zasady per aspera ad astra. $\mathrm{Z}$ zapałem gra też na boisku w piłkę z kolorowymi chłopcami. W medialnym świecie Vujicic znany jest nie tylko ze swojej szczególnej niepełnosprawności, ale kojarzony z aktywnością sportową i przełamywaniem barier społecznych. Jako motywator przemawiał podczas spotkania na stadionie miejskim w Poznaniu w 2015 roku do licznie zgromadzonej publiczności.

Niepełnosprawność fizyczna i społeczna to wątki kulturowe eksploatowane przez Międzynarodową Federację Piłki Nożnej (Fédération Internationale de Football Association, FIFA), zapraszającą do udziału w Mundialach kraje zaniedbane cywilizacyjnie i społecznie, takie jak Brazylia — organizator mistrzostw świata w piłce nożnej w 2014 roku - dającą im tym samym szansę na rozwój. Na stronie internetowej FIFA w zakładce „nasza misja” czytamy, że takimi działaniami „[...] przynosi się nadzieję tym mniej uprzywilejowanym. To, w co wierzymy, jest istotą fair play i solidarności, [...] buduje lepszą przyszłość" (http://www.fifa.com/aboutfifa/organisation/mission.html). W spotach reklamowych FIFA z serii „Dla gry. Dla świata”, emitowanych w przerwach transmisji z najważniejszych zawodów świata (nie tylko meczów piłki 
nożnej), występują entuzjaści futbolu i zawodnicy z najbardziej zacofanych krajów, w tym człowiek fizycznie niepełnosprawny, który archaicznym wehikułem rozwozi w dziurawym wiadrze wapno, wytyczając linie autowe boiska. Za poważny błąd należy uznać fakt, że podczas Mundialu w Afryce „zapomniano” o kibicach niepełnosprawnych. Zgromadzili się przed Stadionem Narodowym RPA w Kapsztadzie i na wózkach protestowali przeciwko dyskryminacji, gdyż nie przewidziano dla nich dostatecznej liczby miejsc [Disabled fans protest lack of space at World Cup sites].

Mistrzostwa świata w piłce nożnej są okazją do propagowania w reklamach telewizyjnych pozytywnych wzorców zachowań. Modelowe pod tym względem są kampanie koncernu VISA, oficjalnego partnera FIFA. W spocie „Ewolucja futbolu" [Visa Football Evolution TV Commercial] zasiadający na fotelu przed telewizorem i zajadający chrupki chłopiec z wyraźną nadwagą, podekscytowany bramką, wybiega $z$ domu i radykalnie zmienia swoje życie. Biegnąc przez wszystkie kontynenty, jedząc tylko owoce, stopniowo dzięki „treningowi” przechodzi wyraźną transformację: młodnieje i szczupleje. W kulminacyjnym momencie wbiega na murawę stadionu podczas meczu i tryumfalnie strzela bramkę. Slogan reklamowy głosi: „Żyje się lepiej, gdy za to, czego potrzebujesz, możesz płacić kartą VISA". Jest to jedna z wielu reklam VISA dopingujących do aktywności ruchowej i niczym nie ograniczonego stylu życia. Wszystkie opierają się na podobnym schemacie: kondycja, sprawność i zdrowie zależą od podmiotu jako czynnego „agregatu społecznego”, a resztę spraw „załatwia” karta kredytowa [Visa's Running Man Ad]. Seria reklam z animowanego od kilku lat cyklu flow pokazuje najprzeróżniejszych ludzi, których mobilność (ułatwiana przez kartę kredytową) ożywia, rewitalizuje i uszczęśliwia. Doświadczają stanu swobodnego przepływu pozytywnej energii, który psycholog społeczny Mihaly Csikszentmihalyi (2005) określał jako flow. W reklamie z 2009 roku główna postać porusza się o kulach, a mimo to jeździ i tańczy na deskorolce [VISA Commercial Flow 2009]. W reklamie z 2011 roku „zwykli ludzie", oderwawszy się od swych codziennych zajęć, startują w maratonie miejskim. W spocie z 2013 roku [New VISA 2013 Fell Faster Flow Faster - Queen Don't Stop] dziarski staruszek o lasce dzięki aktywności fizycznej przechodzi głęboką transformację: pod wpływem ruchu młodnieje, a ożywiony biegiem, omija powolnych niepełnosprawnych na wózkach. W ekscentrycznych adidasach wizytuje szpital po to, by zobaczyć nowo narodzonego wnuka.

Interesujące są reklamy Mistrzostw Świata z 2014 roku, które odbyły się w akompaniamencie licznych głosów krytyki i gwałtownych protestów społecznych w zakochanej w piłce nożnej Brazylii, od lat opisywanej przez socjologa Mauricio Murada (Tiesler, Coelho 2008; Mason 2002). W promocji tego Mundialu dostrzega się dwojakiego rodzaju trendy: lokalne i globalne. Z jednej strony mamy reklamy pokazujące gorącokrwistość Brazylijczyków i ich południowoamerykański temperament, przejawiający się w głośnej muzyce, śpie- 
wie, zmysłowym tańcu (w tym capoeira) oraz zamiłowanie do gry w piłkę nożną, uprawianej boso na plaży (ze słynną Copacabaną włącznie), na piaszczystych skwerach, betonowych podwórkach, ulicach miast i w favelach (pokazywanych jedynie migawkowo i z daleka). FIFA w spotach pokazuje Rio de Janeiro, monumentalne stadiony i przewijające się jak obrazkowy refren migawki z pięknych akcji podbramkowych [FIFA World Cup 2014 Brasil]. W reklamach społecznych obecni są frenetyczni i wielobarwni kibice (w szczególności piękne kobiety), bawiący się przy akompaniamencie głośnej muzyki, entuzjastycznie reagujący na ekwilibrystykę piłką, z czego słynni są brazylijscy zawodnicy [FIFA World Cup Brasil 2014 Promo].

Ten rodzaj reklamy przypomina nieskazitelny folder biura podróży, którego oferta ma wywoływać jedynie pozytywne skojarzenia. Obraz ten jest jeszcze bardziej wzmocniony w reklamie Nike [Nike Football Dare to the Brasilian], będącej zbiorem różnych form i konwencji obrazowania ruchu, w którym nie zabrakło zarówno animacji, jak i komiksu. Mechanizm przekazu jest prosty: zawodnicy rozgrywając mecz na wypełnionym kibicami stadionie przypominają sobie, jakie są ich korzenie społeczne (co ułatwia „wjazd” kamery do ich głów). Przekaz jest identyczny z powszechnymi wyobrażeniami i stereotypami związanymi z proweniencją większości brazylijskich piłkarzy: dzięki talentowi, pracy i „zabawie z piłką” wydobywają się z biedy i trafiają na sam szczyt, „zaczarowując” piłkę na oczach zachwyconej publiczności. A jeśli czynią to niedostatecznie spektakularnie, akcja meczu jest zatrzymywana, jak w filmie, którego reżyser - Oliver Stone - niczym surowy i wymagający trener strofuje zawodników, nakłaniając ich do jeszcze efektywniejszej i bardziej trzymającej w napięciu gry [Promo Directv Mundial Brasil 2014 Oliver Stone]. W jednej z omawianych reklam wystąpił młody mężczyzna z wyraźną nadwagą, z entuzjazmem biegający za piłką.

W reklamach Mundialu 2014 oferowanych przez globalne koncerny, takie jak VISA, na pierwszy plan przebija się ich uniwersalność, z brazylijskimi watkami [VISA World Welcome to the 2014 FIFA World Cup]. Przesłanie tych reklam zdaje się mówić: „jesteśmy wszędzie, także i tu”. Socjolog Richard Giulianotti (2013) zauważa, że piłka nożna, szerzej sport, jest idealnym medium konsolidującym społecznie to, co regionalne i globalne $\mathrm{w}$ jedną glokalną, homogeniczną całość. To dzięki sukcesom w piłce nożnej Szkoci, pokonując Brytyjczyków, stali się znani na całym świecie. Dziś z futbolem na najwyższym poziomie kojarzy się zarówno Anglia, jak i Brazylia oraz Szkocja, ale także Katalonia (FC Barcelona), Hiszpania (Real Madryt), Kraj Basków (Athletic Bilbao). Piłka nożna stała się wyróżnioną dyscypliną, a zyskując status sportu ogólnoświatowego, zmieniła się w lokomotywę napędzającą kolejne rynki zbytu, tworzącą nowe produkty masowego handlu i usług. Jednym z sektorów karmiących się futbolową pożywką są masowe media, absorbujące i redystrybuujące informacje ze sportem związane (Giulianotti, Robertson 2004, 2009). 


\section{Igrzyska olimpijskie - Londyn 2012}

Igrzyska olimpijskie rozegrane w Londynie w 2012 roku były wielkim przedsięwzięciem logistycznym, angażującym ogromne środki finansowe, aktywującym gigantyczny kapitał ludzki i społeczny. Brytyjczycy budując imponujące, funkcjonalne obiekty sportowe nie tylko wzięli na swoje barki rekultywację terenów postindustrialnych, ale także dokonali ważnych inwestycji w przestrzeni kulturowej i społecznej. Na organizatorach igrzysk ciążyła bardzo duża odpowiedzialność, wynikająca $z$ faktu, że infrastruktura obiektów sportowych miała służyć także zawodnikom niepełnosprawnym podczas zawodów paraolimpijskich, zaplanowanych na kilka tygodni po olimpijskich, zwłaszcza że po zatoczeniu szerokiego koła zmagania niepełnosprawnych sportowców „wróciły do źródeł”. Po drugiej wojnie światowej bowiem sport niepełnosprawnych jako element rehabilitacji zainicjował sir Ludwik Gutmann. Zawody weteranów wojennych w szpitalu pod Londynem zapoczątkowały wówczas jedną z największych i najważniejszych imprez sportowych XX i XXI wieku.

Przygotowaniom do XXX Letnich Igrzysk Olimpijskich i XIV Letnich Igrzysk Paraolimpijskich, będących wydarzeniami multimedialnymi, towarzyszyło wiele kampanii informacyjno-społecznych, przygotowanych pomysłowo i $z$ rozmachem, bez zbędnego zadęcia, za to $z$ wyraźnym posmakiem „brytyjskiego czarnego humoru". Telewizja BBC wyemitowała interesujący już choćby przez to, że $z$ akompaniamentem muzyki poważnej, a nie pop, długi, 6,5-minutowy spot odnoszący się do brytyjskości sensu stricto $-\mathrm{z}$ monarchinią $\mathrm{w}$ roli głównej - Królową Elżbietą II oraz Jamesem Bondem [James Bond and The Queen London 2012 Performance], agentem Jej Królewskiej Mości (w osobie Daniela Craiga). Królewskim helikopterem przelatują nad Londynem ponad licznie zgromadzonymi na ulicach kibicami machającymi brytyjskimi flagami i biznesmenami popijającymi drogiego szampana na dachu biurowca. W filmie przewijają się elementy kojarzone $z$ Wielką Brytanią: żołnierze w paradnych futrzanych czapach i z nowoczesną bronią rodzimej produkcji oraz brytyjscy policjanci słynni z tego, że są nieuzbrojeni (Friendly Bobby) w charakterystycznych hełmach. Bohaterzy spotu spoglądają z góry na Big Bena, Piccadilly Circus, $\mathrm{Pa}-$ łac Buckingham i ożywiony pomnik Winstona Churchilla. Przelatują nad Tower Bridge $z$ olimpijskimi symbolami i zastygają nad areną stadionu olimpijskiego. Przy dźwiękach muzyki z bondowskich filmów stworzona jest sugestywna iluzja, że leciwa Królowa w wizytowej sukni wyskakuje ze spadochronem w barwach brytyjskich. Po chwili pojawia się w loży honorowej, a towarzyszy jej prezydent MKOl Jacques Rogge.

W internetowych i telewizyjnych spotach reklamowych, w tym także w wersji animowanej dla dzieci i dorosłych [Wenlock tries the Olympic sports - London 2012; BBC London 2012 Olympic Games], przewijali się celebryci, tacy jak Hugh Grant, Roger Moore, David Beckham oraz wielu innych znanych aktorów i sportowców. Pokazywana była „brytyjskość w pigułce” w całym jej przekro- 
ju społecznym. Przebojem igrzysk okazał się utwór muzyczny „Sport w sercu” w wykonaniu czarnoskórej piosenkarki [Heather Small Proud London 2012], $\mathrm{z}$ olimpijskimi symbolami $\mathrm{w}$ tle i zmaganiami sportowców różnych dyscyplin i konkurencji sportowych w kilku wariacjach wideoklipów. Ich motywem przewodnim jest biegnąca $\mathrm{w}$ dresie przez Londyn dziewczyna, inspirująca do działania tych, którzy się z nią stykają: top-menadżerów z londyńskiego city, zmierzających do biurowców w melonikach (jak szermierze walczący na parasolki), wygimnastykowane uczennice w uniformach szkół średnich, hotelowego boya uprawiającego gimnastykę na walizce, usportowioną młodzież wykonującą baletowe figury, ludzi trzymających $\mathrm{w}$ ręku gazetę niczym pałeczkę w sztafecie podczas biegu do charakterystycznych piętrowych autobusów i „garbatych" taksówek. Ale także: ciemnoskórych zamiataczy ulic (grających miotłami i puszką w curling), emigranta pracującego na budowie (skaczącego wzwyż na metalowej rurze), ubrudzonego smarami korpulentnego mechanika (oś samochodu wraz z kołami podnoszącego jak ciężarowcy), stewardesy w obcisłych uniformach próbujące wyprzedzić się na przejściu dla pieszych, muskularnych wioślarzy na Tamizie. Jak również ludzi $\mathrm{w}$ podeszłym wieku obydwojga płci w niej się kapiących, biegacza miejskiego z protezą nogi uprawiającego jogging i orientalnego niepełnosprawnego na wózku inwalidzkim, grającego $z$ różnokolorowymi kolegami w koszykówkę na obiektach miejskich dostosowanych do ich potrzeb i możliwości. Motywem przewodnim reklam było, obok prezentacji kultury materialnej miasta-gospodarza igrzysk, pokazanie aktywności fizycznej dostępnej dla przedstawicieli wszystkich klas i warstw społecznych. Emitowane przed igrzyskami sporty były obrazową socjologią, która - w odróżnieniu od ewaluującej filozofii - nie ocenia prezentowanych faktów społecznych, ale zwraca na nie uwagę i zachęca do refleksji. W filmach wielokulturowa społeczność Brytyjczyków odgrywa codzienne role: Arabowie, Hindusi i Żydzi sprzedają w swych kramach ulicznych także olimpijskie gadżety.

Samsung i VISA, oficjalni partnerzy MKOl i FIFA, postawili na pomysłowe kampanie reklamowe, których motywem przewodnim jest aktywność fizyczna przeistaczająca bohaterów reklam w postaci fit, odnoszące sukcesy sportowe, mogące rywalizować $z$ najlepszymi zawodnikami świata $\mathrm{w}$ niespodziewanym maratonie miejskim z przeszkodami. W „olimpijskiej” reklamie promującej smartfon [Samsung Galaxy S III Commercial — London 2012 Olympic Games] David Beckham, kopiąc precyzyjnie piłkę, trafia $z$ daleka w bęben ciągnięty po murawie boiska, dając tym samym huczny sygnał do rozpoczęcia zawodów. Na filmie pokazywani są jako jedna wielka rodzina ludzie z różnych kontynentów połączeni uprawianiem sportu (choć różnych dyscyplin i konkurencji). Hasła przewodnie to: „Wszyscy są igrzyskami olimpijskimi” i „Zaprojektowany dla ludzi”. Sympatyczny i zabawny jest sport reklamowy „Londyn w 90 sekund” [Usain Bolt stars in Olympic TV ad], w którym najszybszy sprinter świata Jamajczyk Usain Bolt — w drodze z lotniska na stadion olimpijski ściga się z sędzią sportowym, wykorzystując niekonwencjonalne środki lokomocji. W jednej 
scenie widzimy siedzącą w londyńskim autobusie polską olimpijkę i paraolimpijkę, bezręką Natalię Partykę, będącą ambasadorem zdrowia pokazywanym w reklamówkach zachęcających do aktywności fizycznej, animowanych przez konsorcjum polskich AWF-ów (Ambasador zdrowia Natalia Partyka). Po sukcesach polskich zawodników na igrzyskach paraolimpijskich w Londynie, na których zdobyli aż 36 medali (olimpijczycy zaledwie 10), wzrosło zainteresowanie nimi mediów i pojawiły się pierwsze reklamy z ich wizerunkami.

\section{Igrzyska paraolimpijskie - Londyn 2012}

Po cieszących się dużym zainteresowaniem widzów i mediów igrzyskach paraolimpijskich w Pekinie, które odbyły się w 2008 roku, powstał spot reklamowy zapowiadający londyńskie igrzyska paraolimpijskie. W filmie (Paralympics London 2012), w którym pokazywane były obiekty sportowe, kibice, medale i niepohamowane dążenia zawodników niepełnosprawnych do zwycięstwa, snuje się nostalgiczna opowieść: „Za każdym sportowcem jest marzenie. Za każdym marzeniem stoi wyzwanie. $Z$ każdym wyzwaniem związana jest wola zwycięstwa. Serce narodu. Naszego narodu. Paraolimpiada wraca do domu". Opowiadana historia zawiera dane statystyczne dotyczące minionych pekińskich zawodów: 11 dni zmagań, 20 dyscyplin i konkurencji sportowych, udział reprezentantów ze 160 krajów, ponad 4200 zawodników, 3,8 mld widzów na całym świecie. Film wyprodukowano w kooperacji z Brytyjskim Komitetem Paraolimpijskim (British Paralympics Association, BPA, http://www.paralympics.org.uk) zasłużonej $\mathrm{w}$ pokazywaniu problematyki niepełnosprawności telewizji Channel 4. Partnerem strategicznym przedsięwzięcia była firma Otto Bock, specjalizująca się $\mathrm{w}$ produkcji zaawansowanych technologicznie protez, w tym także wysoko wydajnych protez sportowych; od 1988 roku partner igrzysk paraolimpijskich. Film można odczytać na wiele sposobów, a również tak, że najlepiej przygotowane, lecz puste obiekty sportowe są bezwartościowe bez „wkładu ludzkiego”. W takiej konwencji były pokazywane Europejskie Letnie Igrzyska Olimpiad Specjalnych, których Polska była organizatorem w 2010 roku. W ich reklamie pojawił się udekorowany medalem zawodnik na pustym stadionie [Niczego mi nie brakuje. Oprócz ciebie].

W obawie przed niską oglądalnością i „estetyczną nieatrakcyjnością przekazu" publiczna polska telewizja nie pokazała ceremonii otwarcia londyńskich igrzysk paraolimpijskich, które zainaugurował całkowicie sparaliżowany 70-letni Stephen Hawking [London 2012 Paralympics Opening Ceremony, S. Hawking], jeden z najbardziej rozpoznawalnych fizyków, występujący w popularnym serialu Simps i Star Treck oraz wielu reklamach komercyjnych i społecznych. Dotknięty nieuleczalną chorobą neurodegeneracyjną profesor porusza się na elektrycznym wózku zawierającym komputer, monitor i syntezator mowy umożliwiający mu komunikowanie się. Jego wystąpieniu, odczytanemu przez syntetycznego lektora, towarzyszyło akrobatyczno-sportowe show, z nie- 
pełnosprawną kobietą na wózku inwalidzkim umieszczoną na linie pod dachem sceny. W loży honorowej zasiadała królowa Wielkiej Brytanii. Podczas inauguracji igrzysk mistrz ceremonii, witając niepełnosprawnych zawodników „W domu”, mówił o wielu „granicach do przekroczenia” i „barierach do przełamania”, co jest możliwe dzięki sportowi.

Channel 4 wyemitował imponujący rozmachem, porywający spot filmowy „Spotkaj superludzi” [Channel 4 Paralympics Meet the Superhumans]. Jego bohaterami są niepełnosprawni zawodnicy, pokazywani bez ukrywania ich fizycznych braków i ułomności, płaczący z żalu po przegranej, bez pardonu walczący o zwycięstwo. Postaci pokazywane są jako „bohaterzy”, „brygada do zadań specjalnych" - konwencja z filmów akcji i sensacyjnych seriali. Film porusza dynamiką i żywym obrazem oraz narastającym brzmieniem muzyki. Wykorzystano sceny z epizodów wojennych, wypadków samochodowych itp. Dzięki zabiegom producentów tego zaangażowanego społecznie spotu nie widzi się cielesnych mankamentów i niepełnosprawności, ale przede wszystkim dostrzega się ludzi w ich sportowych zmaganiach.

Maria Grzegorzewska — twórczyni pedagogiki specjalnej — twierdziła: „nie ma kaleki — jest człowiek”. Człowiek w swym egzystencjalnym wymiarze, niezależnym od liczby posiadanych kończyn, rodzaju towarzyszących mu dysfunkcji i stopnia cielesnych ubytków. Najdobitniej wyraża to scenariusz mocnego obrazu filmowego, powstałego dzięki firmie Samsung, zatytułowanego „Sport nie dba o to, kim jesteś. Każdy może wziąć w nim udział" [Paralympics — London 2012 - Sport doesn't care who you are]. Na filmie trenerzy niepełnoprawnych zawodników różnych dyscyplin i konkurencji sportowych, często także niepełnosprawni, niczym kaprale bezlitośnie „pastwią się” nad podopiecznymi, ale bynajmniej nie po to, by ich upokorzyć, lecz w celu doprowadzenia do zwycięstwa. Konwencję tego spotu podtrzymano na Igrzyskach Paraolimpijskich w Soczi w 2014 roku. Samsung przygotował wówczas kilkuodcinkowy reklamowy serial pod wspólnym tytułem „Jaki jest twój problem? Sport nie dba o to" [What's Your Problem? Sport Doesn't Care. Sochi 2014. Paralympic Games], z niepełnosprawnymi zawodnikami, w tym także Polakami.

$\mathrm{Na}$ igrzyskach olimpijskich i paraolimpijskich w Londynie wystąpił słynny beznogi zawodnik z RPA Oscar Pistorius, który prawo do rywalizacji z pełnosprawnymi sportowcami wywalczył sądownie. Aby czynnie uczestniczyć w prestiżowych zawodach, musiał zdobyć minimum olimpijskie. Pistorius występuje $\mathrm{w}$ wielu reklamach komercyjnych, nie ukrywając braku kończyn (jako narrator opowiada o ich utracie), ale koncentruje się na determinacji i mocy ducha, sile i sprawności fizycznej. Są to reklamy suplementów sportowych, takich jak napój Powerade [Oscar Pistorius - Bring it on] i dóbr luksusowych, na przykład wody toaletowej [A Men by Thierry Mugler Fragrance — Oscar Pistorius], mającej gwiazdę na opakowaniu i na flakonie - symbol korespondujący z gwiazdą, jaką Pistorius stał dzięki sportowi. W internecie często oglądany jest film, w którym bierze udział w wyścigu z koniem arabskim w Katarze — kraju, który 
będzie gospodarzem pierwszych zimowych mistrzostw świata w piłce nożnej, rozgrywanych na przełomie 2022-2023, co jest ewenementem w historii futbolu [Oscar Pistorius races a horse in Qatar].

Pistorius wystąpił w reklamach firmy Nike. Intrygujący „Ludzki łańcuch” [Nike Presents - Human Chain] pokazuje zmultiplikowane bolesne upadki sportowców. Dzięki hartowi ciała i sile ducha podnoszą się i zwyciężają, czego przykładem jest Pistorius. Reklama o symptomatycznym tytule „Moje ciało jest moją bronią" [Nike - My body is my Weapon], w której obrazy kojarzą się z byciem „szybszym niż kula”, została wycofana z publicznego obiegu po tym, jak Pistorius zastrzelił swoją narzeczoną, lecz tym bardziej jest oglądana $\mathrm{w}$ internecie. Zawodnik ten nie był jedynym niepełnosprawnym sportowcem w kampaniach komercyjnych produktów firmy Nike. Innym bohaterem reklam jest paraolimpijczyk Rohan Mario Murphy - zapaśnik eksponujący nadzwyczajne możliwości ruchowe [Rohan Murphy Nike Commercial], trenuje i walczy na zapaśniczej macie także z pełnosprawnymi zawodnikami.

W analizowanych reklamach bezpośrednio związanych z wielkimi imprezami sportowymi dostrzega się trojakiego rodzaju tendencje. Pierwsza z nich najdobitniej przejawia się w Stanach Zjednoczonych i związana jest z dyscyplinami, na które najżywiej reagują Amerykanie; przede wszystkim z futbolem amerykańskim. Finały Super Bowl koncentrują uwagę na będącej kibicowskim obyczajem konsumpcji, czyniąc ją niemal obowiązkową. Jeśli w reklamach emitowanych w tym czasie pojawiają się newralgiczne kwestie społeczne, takie jak aktywność fizyczna, niepełnosprawność, starość i zdrowie (ale, co ciekawe, nie otyłość), to nadal związane są one z komercją. Komercją „ubraną” w patriotyczne i społecznie odpowiedzialne „szaty”, ale mimo wszystko z konsumpcją, imputowaną odbiorcom jako „amerykański styl życia”. W Stanach Zjednoczonych reklamy towarzyszące "kultowym” dyscyplinom sportowym, takim jak baseball, futbol amerykański, koszykówka i hokej na lodzie, wzmacniają obraz, „prawdziwego Amerykanina”, który wie, co dobre i potrafi to zdobyć. Podczas finału Super Bowl w 2016 roku główną nagrodą dla kibica była pizza posypana złotem.

Drugi rodzaj reklam to te, które podczas globalnych imprez sportowych Euro, Mundial, igrzyska olimpijskie i paraolimpijskie - emitują światowe koncerny i ponadnarodowe organizacje, takie jak UEFA, FIFA, MKOl. Reklamy te cechuje kosmopolityzm i uniwersalizm, przejawiający się w sposobie przekazu obrazów. Są one "glokalne” w tym sensie, że wartości ponadnarodowe aplikują i prezentują na gruncie lokalnym, wykorzystując przy tym aktorów społecznych będących celebrytami (Beckham, Messi, Ronaldo), osoby niepełnosprawne (Vujicic, Pistorius, Hawking), ważne społeczne postaci (laureaci pokojowych nagród Nobla, cenieni sędziowie sportowi). Choć głównym celem tych 
reklam jest zwiększenie konsumpcji (koncerny i różne instytucje nastawione są na zwiększanie zysków), to jednak trącają czułe struny, podejmują wątki, na które wrażliwa jest widownia sportowa. Lokalny koloryt (barwy kraju-gospodarza, flagi, charakterystyczne obiekty, stadiony narodowe) przewijają się w nich niczym refren, unika się jednak głębszego zaangażowania, odniesień do lokalnych konfliktów, problemów społecznych. W reklamach Mundialu 2014 w Brazylii nie ma biedy, faveli, korupcji, przestępczości, choć problemy te były głównymi hasłami w brutalnie rozpędzanych przez policję manifestacjach ulicznych („,chleba za miast igrzysk”). Świat prezentowany w tych reklamach jest światem idealnym, odświętnym, utopijnym: króluje w nim bezczasowa zabawa beztroskich młodych ludzi. Pod tym względem reklamy te mogłyby być wyświetlane wszędzie i zawsze, nie tylko podczas imprez sportowych, ale także innych ważnych wydarzeń społecznych, na przykład rocznic lub świąt państwowych.

Trzeciego rodzaju reklamy, obejmujące także obrazy komercyjne, są społecznie zaangażowane. Stanowią jakby „obrazową socjologię”: skupione są na takich problemach, jak aktywność ruchowa, choroby cywilizacyjne, niepełnosprawność, starość, zdrowie. Te wrażliwe społecznie reklamy realizują „misję” i są świadectwem odpowiedzialności społecznej koncernów i organizacji, które je emitują. W obrazach tych wykorzystuje się ironię, humor, żart; porozumiewawczo „mruga się okiem” w stronę widza, wysyłając komunikat na temat tego, jaki stan jest oczekiwany w wersji wzorcowej. Przykładem są tworzone od lat kampanie reklamowe koncernu VISA, pokazujące, jak pod wpływem aktywności fizycznej (oraz kart kredytowych) można zmienić życie na lepsze, mimo choroby, nadwagi, niepełnosprawności, wieku. Podobny mechanizm przekazu treści przewija się w kampaniach UEFA i FIFA. Ten rodzaj reklam - uczących poprzez zabawę - stosuje i stosować będzie, przy wykorzystaniu mass mediów, w tym także interaktywnych mediów internetowych, coraz więcej krajów w ramach programów rządowych. Wiele kampanii reklamowych aktywizujących ruchowo i zachęcających do zmiany nawyków zlecają ministerstwa zdrowia i sportu, opłacane $z$ programów Unii Europejskiej. Media masowe, docierające do ogromnej liczby widzów, są potężnym narzędziem komunikacji i przekazu. Dają one szansę na zmianę sposobu spędzania czasu wolnego i popychają w stronę pożądanego, projektowanego zdrowego stylu życia. Wiesław Łukaszewski o kompulsywnej aktywności sportowej napisał: „[...] zainteresowanie wyglądem staje się poniekąd obywatelskim obowiązkiem. Uroda stanowi część osobistego, a w jakiejś części też społecznego, kapitału" (Łukaszewski 2014, s. 24, 2011; Łuszczyńska 2011; Sahaj 2010, 2013b).

Osobną kategorię stanowią akcje niekomercyjne, kampanie i reklamy odpowiedzialne społecznie pokazujące dany kraj i jego społeczeństwo. Globalne imprezy sportowe, które przez pewien czas skupiają uwagę widzów z całego świata (miliardowa widownia), są w stanie w syntetyczny sposób zobrazować kulturę i przekrój danego społeczeństwa. Kraje totalitarne - Chiny, Korea, 
Rosja - po wielekroć zabiegały o organizację globalnych imprez sportowych, mając nadzieję, że dzięki nim pokażą światu „ludzką twarz”, zmienią negatywne i stereotypowe wyobrażenia, repozycjonują się w świadomości masowego odbiorcy. Szczególnym przykładem jest Rosja, która w poczuciu mocarstwowości przed, w trakcie igrzysk lub tuż po nich dokonuje inwazji na słabsze kraje; tak też zrobiła w 2014 roku. W roku 2012 Wielka Brytania pokazała się jako kraj nowoczesny i z tradycjami, w którym żyć mogą ludzie wszystkich ras i wyznań. Przy okazji, rewolucjonizując przekaz dotyczący osób niepełnosprawnych, zmieniła obowiązujące standardy. W trakcie igrzysk paraolimpijskich w Soczi firma Samsung dokonała zwrotu paradygmatycznego, „odbrązawiając" paraolimpijczyków i pokazując ich w ludzkim, egzystencjalnym wymiarze (reklamy te stworzył też polski reżyser Tomasz Bagiński). Dzięki takim działaniom dyskryminowane i spychane na margines życia społecznego grupy społeczne mają szansę na inkluzję społeczną i zwiększony udział w sporcie. Socjolog Klaus Heinemann (1999, s. 81) przewiduje, że w postmodernistycznych społeczeństwach europejskich do sportu zdecydowanie wkroczą „,...] ludzie w starszym wieku, kobiety, przedstawiciele niższych klas społecznych, mniejszości etnicznych, cudzoziemscy robotnicy, niepełnosprawni”.

Mass media w krótkim czasie, synchronicznie docierając do miliardów ludzi na całym świecie, nie tylko reportersko transmitują, ale także projektują i zmieniają świat. Tym samym na mediach publicznych i organizacjach sportowych ciąży duża odpowiedzialność społeczna. Mogą one wydobyć z niebytu i zapewnić „widzialność” dyskryminowanym lub marginalizowanym aktorom społecznym i pomóc $\mathrm{w}$ przełamywaniu barier i rozpowszechnionych stereotypów z nimi związanych. Sport na każdym poziomie - zarówno amatorskim, jak i profesjonalnym - w coraz większym stopniu staje się uniwersalną płaszczyzną integracji i komunikacji międzyludzkiej, służącą przekraczaniu granic i przełamywaniu barier kulturowych i społecznych.

Badania fenomenu kulturowego, jaki stanowią medialne akcje i kampanie społeczne oraz zaangażowane społecznie reklamy i spoty filmowe związane $z$ globalnymi imprezami sportowymi, stanowią rzadkość na gruncie nauk o kulturze fizycznej. Wyniki niewielu badań prowadzonych przez polskich przedstawicieli nauk kulturowych i społecznych także nie były dotychczas szerzej prezentowane $\mathrm{w}$ periodykach o proweniencji sportowej. Wpływ masowych mediów na życie społeczne jest dobrze znany i opisany w literaturze przedmiotu, jednak dopiero od niedawna zaczęto to wykorzystywać na większą skalę do przełamywania barier i stereotypów związanych z niepełnosprawnością za sprawą widowisk sportowych. Dobrym przykładem jest tu bardzo duże zainteresowanie mediów igrzyskami paraolimpijskimi, ale dopiero od czasu tych rozgrywanych w Pekinie w 2008 roku. Zdecydowany prze- 
łom w pokazywaniu zmagań niepełnosprawnych zawodników nastąpił w Londynie w 2012 roku, choć do pewnego stopnia był związany z medialną wrzawą wywołaną przez Oscara Pistoriusa. Zainteresowanie sportem osób niepełnosprawnych, wsparte reklamami, utrzymało się w Soczi w 2014 roku, zostało jednak umniejszone i zepchnięte $\mathrm{w}$ cień przez konflikt rosyjsko-ukraiński. Socjolog Stanley D. Eitzen stwierdził: „Sport jest odbiciem społeczeństwa. Cierpi na takie same dolegliwości, jakie trawią społeczeństwo, w którym funkcjonuje" (Eitzen 1981, s. 412). Media są lustrem odzwierciedlającym rzeczywistość, jednakże w sposób kulturowo przetworzony. Niekiedy jest to obraz astygmatyczny lub sprokurowany, często bywa elementem inżynierii społecznej, zapośredniczającej sposób widzenia świata. O tym, że świat nie jest taki, jakim jawi się widzom, wiedzą nie tylko filozofowie - esse est percipi, jak głosił Georg Berkeley - ale i komentatorzy sportowi oraz sprawozdawcy telewizyjni (Bauer, Chudziński 2012; Goban-Klas 2011; Gwóźdź 2003; Rowe 2004).

\section{BIBLIOGRAFIA}

Antonowicz Dominik, Wrzesiński Łukasz, 2009, Kibice jako wspólnota niewidzialnej religii, „Studia Socjologiczne", nr 1.

Bauer Zbigniew, Chudziński Edward (red.), 2012, Dziennikarstwo i świat mediów. Nowa edycja, Universitas, Kraków.

Bausinger Herman, 2005, Małe święta na co dzień: piłka nożna, w: Leszek Kolankiewicz (red.), Antropologia widowisk. Zagadnienia i wybór tekstów, Uniwersytet Warszawski, Warszawa.

Burnett Cora, 2015, Assessing the Sociology of Sport: On Sport for Development and Peace, „International Review for the Sociology of Sport", t. 50, nr 4-5, s. 385-390.

Csikszentmihalyi Mihaly, 2005, Przeptyw. Psychologia optymalnego doświadczenia, tłum. Magdalena Wajda-Kacmajor, Moderator, Taszów.

Eitzen Stanley D., 1981, Sport and Deviance, w: Günther R.F. Lüschen, George H. Sage (red.), Handbook of Social Science of Sport, Stipes Publishing, Illinois.

Foer Franklin, 2006, Jak futbol wyjaśnia świat czyli nieprawdopodobna teoria globalizacji, tłum. Anna Czarnecka, Red Horse, Lublin.

Gadamer Hans Georg, 2011, O skrytości zdrowia, tłum. Andrzej Przyłębski, Media Rodzina, Poznań.

Giulianotti Richard, 2013, Globalizacja i piłka nożna. Socjologiczna analiza głównych tematów i zagadnień, tłum. Arkadiusz Peisert, w: Radosław Kossakowski i in. (red.), Futbol i cała reszta. Sport w perspektywie nauk społecznych, Orbis Exterior, Pszczółki.

Giulianotti Richard, Robertson Roland, 2004, The Globalization of Football: A Study in the Glocalisation of the 'Serious Life', „British Journal of Sociology”, t. 55, nr 4, s. 545-568.

Giulianotti Richard, Robertson Roland, 2009, Globalization and Football, Sage, London.

Goban-Klas Tomasz, 2011, Wartki nurt mediów. Ku nowym formom społecznego życia informacji, Universitas, Kraków.

Gwóźdź Andrzej (red.), 2003, Media - eros - przemoc. Sport w czasach popkultury, Universitas, Kraków.

Heinemann Klaus, 1999, Sport w spoteczeństwie postmodernistycznym, „Sport Wyczynowy”, nr 3-4.

Horne John, 2015, Assessing the Sociology of Sport: On Sports Mega-Events and Capitalist Modernity, „International Review for the Sociology of Sport”, t. 50, nr 4-5, s. 466-471. 
Jackson Steven J., 2015, Assessing the Sociology of Sport: On Media, Advertising and the Commodification of Culture, „International Review for the Sociology of Sport”, t. 50, nr 4-5, s. 490-495.

Jagielski Wojciech, 2013, Trębacz z Tembisy. Droga do Mandeli, Znak, Kraków.

Jan Paweł II, 2005, Rachunek sumienia dla sportu, „Sport Wyczynowy”, nr 3-4.

Judt Tony, 2008, Powojnie. Historia Europy od roku 1945, tłum. Robert Bartołd, Rebis, Poznań.

Judt Tony, 2012, Pensjonat pamięci, tłum. Hanna Jankowska, Wydawnictwo Czarne Wołowiec.

Kiedrowski Michał, 2014, Co warto wiedzieć o Super Bowl 2014? (http://www.sport.pl [01.02.2016]).

Kiedrowski Michał, 2016, Pasjonaci sportu w TV, „Gazeta Wyborcza”, 25 stycznia.

Krawczyk Zbigniew, 2011, Powstanie i rozwój socjologii kultury fizycznej, w: Zbigniew Dziubiński, Zbigniew Krawczyk (red.), Socjologia kultury fizycznej, AWF, Warszawa.

Lipiec Józef, 2007, Pożegnanie z Olimpia, Wydawnictwo Fall, Kraków.

Lipoński Wojciech, 2012, Historia sportu na tle rozwoju kultury fizycznej, Wydawnictwo Naukowe PWN, Warszawa.

Łukaszewski Wiesław, 2011, Udręka życia, Smak Słowa, Sopot.

Łukaszewski Wiesław, 2014, Odchudzanie ze strachu przed śmiercia, „Gazeta Wyborcza”, 22-23 marca.

Łuszczyńska Aleksandra, 2011, Psychologia sportu i aktywności fizycznej. Zagadnienia kliniczne, Wydawnictwo Naukowe PWN, Warszawa.

Mason Tony, 2002, Pasja milionów. Piłka nożna w Ameryce Południowej, tłum. Piotr Bratkowski, Wydawnictwo Marabut, Gdańsk.

Mazurkiewicz Michał, 2014, Baseball i piłka nożna w amerykańskiej i polskiej kulturze jako przykład wspótczesnego mitu i rytuału, Uniwersytet Jana Kochanowskiego, Kielce.

McLuhan Marshall, 2004, Zrozumieć media. Przedłużenia człowieka, tłum. Natalia Szczucka, Wydawnictwa Naukowo-Techniczne, Warszawa.

Ostrowska Antonina, 2001, Niepetnosprawni w społeczeństwie 1933-2013, Wydawnictwo IFIS PAN, Warszawa.

Putnam Robert D., 2008, Samotna gra w kręgle. Upadek i odrodzenie wspólnot lokalnych w Stanach Zjednoczonych, tłum. Przemysław Sadura, Sebastian Szymański, Wydawnictwa Akademickie i Profesjonalne, Warszawa.

Rowe David (red.), 2004, Sport, Culture and the Media, Open University Press, Berkshire.

Rymarczyk Piotr, 2011, Kultura masowa i kultura fizyczna, w: Zbigniew Dziubiński, Zbigniew Krawczyk (red.), Socjologia kultury fizycznej, AWF, Warszawa.

Sahaj Tomasz, 2009, Kibicowanie futbolowe, religia $i$ socjologia sportu, „Studia Socjologiczne”, nr 3.

Sahaj Tomasz, 2010, Choroba i niepetnosprawność w kontekście aktywności ruchowej i sportu. Szkice spoteczne, AWF, Poznań.

Sahaj Tomasz, 2012a, Kibice niepetnosprawni na stadionach pitkarskich — refleksje po Euro 2012, „Sport Wyczynowy", nr 3.

Sahaj Tomasz, 2012b, Niepetnosprawni kibice — nadzieja i szansa Euro 2012, „Niepełnosprawność i Rehabilitacja", nr 2.

Sahaj Tomasz, 2013a, Niepetnosprawni i niepetnosprawność w mediach, Instytut Rozwoju Służb Społecznych, Warszawa.

Sahaj Tomasz, 2013b, Niepetnosprawni i niepetnosprawność $w$ medialnych kampaniach spotecznych towarzyszacych globalnym imprezom sportowym, „Sport Wyczynowy”, $\mathrm{nr} 2$.

Sztompka Piotr, 2008, Życie codzienne - temat najnowszej socjologii, w: Piotr Sztompka, Małgorzata Bogunia-Borowska (red.), Socjologia codzienności, Znak, Kraków.

Tiesler Nina C., Coelho Joao N. (red.), 2008, Globalised Football: Nations and Migration, the City and the Dream, Routlege, London-New York.

Zowisło Maria, 2007, Sport jako sztuka. Wokót postmodernistycznej estetyzacji sportu, „Edukacja Filozoficzna", nr 44, s. 27-39. 


\section{PHYSICAL ACTIVITY, (DIS)ABILITY, AND HEALTH IN COMMERCIALS} DURING HIGH-PROFILE SPORTS EVENTS

\section{Summary}

The aim of this article is to examine the commercials broadcast during prestigious sports events, such as the Super Bowl in the United States, the Olympic Games and Paralympic Games, and the World Cup and European Championship in football. The author uses the qualitative method and analyzes the content of the commercials as texts of contemporary culture. Mass media is the universal communication platform of the 'global village.' There is a certain expectation that it will be socially responsible, which is reflected in commercials involving disabled persons, or in those encouraging the audience to adopt an active, healthy lifestyle and to engage in sport as an antidote to civilizational diseases.

\section{Key words / słowa kluczowe}

physical activity / aktywność fizyczna; mass media / media masowe; fitness / sprawność; advertising / reklama; sport / sport; health / zdrowie 